\title{
KEBIJAKAN PIDANA DALAM PENGATURAN ASAS PERADILAN CEPAT, SEDERHANA DAN BIAYA RINGAN DALAM HUKUM ACARA PIDANA
}

\author{
Oleh : \\ Raden Achmad Syarnubi * \\ Bunyamin Alamsyah* \\ Amir Syarifuddin *
}

\begin{abstract}
ABSTRAK
Hukum bertujuan untuk mewujudkan kepastian dalam hubungan antar manusia, yaitu menjamin prediktabilitas, dan juga bertujuan untuk mencegah jangan sampai hak yang terkuat yang berlaku. Salah satu bentuk penghormatan terhadap hak-hak selaku pelanggar hukum sebagai bagian dari warga negara, adalah diaturnya ketentuan tentang asas-asas hukum acara pidana nasional, yang memuliakan harkat dan martabat manusia, yang disangkakan, didakwakan dan/atau dinyatakan terbukti bersalah melakukan pelanggaran hukum pidana. Untuk menjamin terselenggaranya proses peradilan yang cepat, KUHAP mengatur sejumlah ketentuan, antara lain mengenai batas waktu penahanan. Dengan adanya penetapan batas waktu penahanan, proses peradilan mulai dari penyidikan, penuntutan, pemeriksaan dan penjatuhan putusan oleh sidang pengadilan, diharapkan dapat berlangsung secara cepat, sederhana dan biaya ringan. Namun ditemui adanya norma yang kosong (vacuum of norm) di dalam KUHAP terkait pemenuhan asas peradilan yang cepat, sederhana dan biaya ringan, terdapat yang mengatur tentang batas waktu penyelesaian perkara pidana terhadap tersangka atau terdakwa yang tidak dikenakan penahanan. Kekosongan norma hukum tersebut sangat berpotensi melemahkan penegakan hukum karena menimbulkan ketidak-pastian hukum, ketidak-adilan hukum, dan ketidakmanfaatan hukum di tengah masyarakat.
\end{abstract}

Kata Kunci: Asas Peradilan Cepat Sederhana Biaya Ringan, Hukum Acara Pidana

\section{A. Latar Belakang Masalah}

Amanat konstitusi negara tentang bentuk negara hukum (rechtsstaat) t, merupakan perwujudan dari dari Teori Negara Hukum, yang antara lain dikemukakan oleh A.V. Dicey melalui teorinya "rule of law"seperti dikutip Padmo Wahjono, bahwa "ciri penting setiap negara hukum adalah supremasi hukum (supremacy of law), kesamaan di depan hukum (equality before the law) dan proses hukum yang adil (due process of law)". ${ }^{1}$

\footnotetext{
* Hakim Pengadilan Agama Muara Sabak, Alumni Program Magister Ilmu Hukum Unbari.

* Pengajar Program Magister Ilmu Hukum Unbari.

* Pengajar Program Magister Ilmu Hukum Unbari. 1982, hal. 7.

${ }^{1}$ Padmo Wahjono, Indonesia Negara Berdasarkan Atas Hukum, Ghalia Indonesia, Jakarta,
} 
Dalam rangka perubahan Undang-Undang Dasar Negara Republik Indonesia Tahun 1945 yang keempat tahun 2002, Utrecht, berpandangan bahwa konsepsi Negara Hukum atau "Rechtsstaat" yang sebelumnya hanya tercantum dalam Penjelasan UUD 1945, telah dirumuskan dengan tegas dalam Pasal 1 ayat (3) yang menyatakan, "Negara Indonesia adalah Negara Hukum.” Dalam konsep Negara Hukum itu, diidealkan bahwa yang harus dijadikan panglima atau supreme dalam dinamika kehidupan kenegaraan adalah hukum, bukan politik ataupun ekonomi. ${ }^{2}$

Yang dimaksud dengan supremasi hukum (supremacy of law) dijelaskan oleh Bernard Arief Sidharta bahwa:

Negara yang di dalamnya semua penggunaan kekuasaan harus selalu ada landasan hukumnya dan dalam kerangka batas-batas yang ditetapkan oleh hukum. Jadi pemerintahan yang dikehendaki adalah pemerintahan berdasarkan dengan dan oleh hukum (rule by law dan rule of law). ${ }^{3}$

Sedangkan pengertian dari kesamaan di depan hukum (equality before the law), adalah bahwa "pemerintah dan para pejabatnya harus memberikan perlakuan yang sama kepada semua orang, dan undang-undang juga berlaku sama untuk semua orang". 4

Mengenai unsur-unsur negara hukum modern, menurut J. Stahlharuslah memenuhi empat syarat pokok, yakni : (1) Negara harus melindungi hak-hak asasi manusia, (2) Harus ada pemisahan dan pembagian kekuasaan, (3) Pemerintahan harus berdasarkan hukum, (4) Harus ada peradilan administrasi. ${ }^{5}$ Paul Scholtenhanya mengemukkan tiga unsur, yaitu : (1) Diakuinya hak-hak asasi manusia, (2) Adanya pemisahan kekuasaan, (3) Adanya pemerintahan yang berdasarkan undang-undang. ${ }^{6}$

Kemudian Sri Soemantrimenyebut empat unsur, ialah: (1) pemerintah dalam melaksanakan tugas dan kewajibannya harus berdasarkan hukum atau peraturan perundangan, (2) Adanya jaminan hak asasi manusia (warga negara), (3) Adanya Pembagian kekuasaan dalam negara, (4) Adanya pengawasan dari badan peradilan (rechterlijke controle) ${ }^{7}$

\footnotetext{
${ }^{2}$ Utrecht, Pengantar Hukum Administrasi NegaraIndonesia, Ichtiar, Jakarta, 1962, hal. 9

${ }^{3}$ Bernard Arief Sidharta, Refleksi Tentang Struktur Ilmu Hukum, Mandar Maju, Bandung, 2000,

${ }^{4}$ Ibid.

5 S.F. Marbun, Peradilan Administrasi Negara dan Upaya Administratif di Indonesia,

${ }^{6}$ M. Tahir Azhary, Negara Hukum Indonesia, Jakarta: UI Press, 1995, hal. 9.

${ }^{7}$ Sri Soemantri, Bunga Rampai Hukum Tata Negara, Alumni, Bandung, 1992, hal.10
} hal. 48 . Yogjakarta, Liberty, 1997, hal. 9 
Karena itu, sistem konstitusi yang menjadi salah satu gagasan normatif negara hukum, haruslah mengikuti empat prinsip imperatif konstitusionalisme, yaitu:

(1) Seluruh kekuasaan politik harus tunduk pada hukum.

(2) Adanya jaminan dan perlindungan hak-hak asasi manusia.

(3) Peradilan yang bebas dan mandiri,

(4) Akuntabilitas publik, sebagai sendi utama kedaulatan rakyat. Supremasi hukum, merupakan ide normatif untuk mencegah atau menghindari terjadinya kesewenangwenangan dan terjaminnya equality before the law. ${ }^{8}$

Selain itu, ide "negara berdasarkan hukum", memunculkan keharusan imperative agar seluruh kekuasaan politik tunduk pada hukum. Perlindungan hak-hak asasi manusia, merupakan ide normatif untuk menjamin hak-hak rakyat sebagai pihak yang diperintah. ${ }^{9}$

Checks and balances merupakan ide normatif untuk menghindari terjadinya absolutisme dalam pelaksanaan kekuasaan negara dan untuk menjamin berjalannya demokrasi. ${ }^{10}$ Sedangkan rechterlijke controle, ${ }^{11}$ merupakan ide normatif untuk menghindari terjadinya pemaksaan kehendak oleh pihak yang kuat terhadap yang lemah, termasuk antara yang memerintah dan yang diperintah.

Demikian pula menurut Jan Michielyang berpandangan : "semakin baik hukum itu berfungsi, maka semakin tinggi tingkat kepastian hukum. Sebaliknya, bila suatu negara tidak memiliki sistem hukum yang berfungsi secara otonom, maka semakin kecil pula tingkat kepastian hukumnya". 12

Di dalam lapangan hukum pidana, pengertian perlakuan yang sama di depan hukum, dikemukakan oleh Mardjono Reksodiputro bahwa:

Perlakuan yang sama ini tidak hanya harus ditafsirkan disini dalam menghadapi tersangka dan terdakwa yang berbeda dalam kedudukan atau kekayaan, tetapi harus lebih dari itu. Asas ini serupa dengan yang terdapat dalam Pasal 6 dan 7 Universal Declaration of Human Rights (UDHR) dan Pasal 16 International Covenant on Civil and Political Rights (ICCPR). Oleh karena itu, pemahaman kita akan istilah "sama" disini adalah wajib

\footnotetext{
1966, hal. 11

${ }^{10}$ M. Tahir Azhary, Op.Cit, hal. 9.

${ }^{11}$ Sri Soemantri, Op. Cit, hal.10.

12 Jan Michiel Otto dalam Tristam Moeliono,Kepastian Hukum di Negara Berkembang, Jakarta: Komisi Hukum Nasional Republik Indonesia, 2003, hal. 5-6
}

${ }^{8}$ M. Mahfud MD, Demokrasi dan Konstitusi di Indonesia, Rineka Cipta, Jakarta, 2000, hal. 28.

${ }^{9}$ C.F. Strong, Modern Political Constitutions, London,ELBS and Singwick \& Jakson Limited, 
dihindarinya diskriminasi berdasarkan : "race, colour, sex, language, religion, political or other opinion, national or social origin, property, birth or other status". 13

Sementara itu, mengenai proses hukum yang adil (due process of law), diartikan oleh Bernard Arief Sidharta bahwa "negara hukum menjamin terselenggaranya proses peradilan yang bebas, objektif, imparsial atau tidak memihak, adil dan manusiawi". ${ }^{14}$

Senada dengan Bernard Arief Sidharta, Mardjono Reksodiputro mengemukakan bahwa "Proses hukum yang adil (due process of law), adalah proses hukum dimana di dalamnya hak-hak tersangka, terdakwa dan terpidana dilindungi dan dianggap sebagai bagian dari hak-hak warga negara (civil rights) dan karena itu bagian dari HAM". ${ }^{15}$

Pada sisi lain, proses hukum yang adil tidak dapat dipisahkan dari tujuan penegakan hukum. Terkait dengan hal itu, terdapat sejumlah faktor penting, yang menentukan keberhasilan penegakan hukum. Menurut Gustav Radbruch sebagaimana dikutip Sudikno Mertokusumo, hakekat dari ditegakkannya hukum adalah sebagai berikut:

Hukum berfungsi sebagai perlindungan kepentingan manusia, dan melalui penegakan hukumlah hukum itu menjadi kenyataan. Dalam menegakkan hukum ada tiga unsur yang selalu harus diperhatikan, yaitu keadilan (gerechtigkeit), kepastian hukum (rechtssichereit) dan kemanfaatan (zweckmassigkeit). ${ }^{16}$

Asas keadilan sebagai tujuan hukum didasarkan pada kenyataan bahwa dalam suatu masyarakat atau negara, kepentingan perseorangan dan kepentingan golongan-golongan manusia selalu bertentangan satu sama lain. Pertentangan inilah yang menyebabkan pertikaian bahkan peperangan. Hukum mempertahankan perdamaian dan menimbang kepentingan yang bertentangan secara teliti dengan mengusahakan terjadinya suatu keseimbangan di antara kepentingan-kepentingan tersebut, sehingga hukum dapat mencapai tujuan adildengan adanya keseimbangan antara kepentingan-kepentingan yang dilindungi bagi setiap orang untuk memperoleh bagiannya melalui peraturan yang memuat

\footnotetext{
${ }^{13}$ Mardjono Reksodiputro, Hak Asasi Manusia Dalam Sistem Peradilan Pidana, Kumpulan Karangan Buku Ketiga, Pusat pelayanan Keadilan dan Pengabdian Hukum (d/h Lembaga Kriminologi) Universitas Indonesia, jakarta, 2007, hal. 36.

${ }^{14}$ Bernard Arief Sidharta, Op. Cit., hal. 200.

${ }^{15}$ Mardjono Reksodiputro, Op. Cit., hal. 53.

${ }^{16}$ Sudikno Mertokusumo, Mengenal Hukum Suatu Pengantar, Liberty, Yogyakarta, 2007, hal. 160.
} 
kesinambungan kepentingan-kepentingan yang dalam Bahasa Latinnya adalah: "ius suum cuique tribuere". ${ }^{17}$

Mengenai ukuran keadilan itu sendiri, diakui oleh Mochtar Kusumaatmadja dan B. Arief Sidharta sebagai sesuatu yang relatif. Keduanya mengemukakan bahwa definisi tentang apa yang disebut dengan adil akan berbeda-beda bagi setiap individu. Selengkapnya dinyatakan bahwa:

Tidak berlebihan apabila keadilan itu sesuatu yang sukar untuk didefinisikan, tetapi bisa dirasakan dan merupakan unsur yang tidak bisa tidak harus ada dan tidak dipisahkan dari hukum sebagai perangkat asas dan kaidah yang menjamin adanya keteraturan (kepastian) dan ketertiban dalam masyarakat. ${ }^{18}$

Kepastian hukum, sebagaimana keadilan dan kemanfaatan hukum, adalah sesungguhnya sebuah doktrin. Doktrin kepastian hukum mengajarkan kepada setiap pelaksana dan penegak hukum untuk (demi terkendalikannya kepatuhan warga agar ikut menjaga ketertiban dalam setiap aspek kehidupan) mendayagunakan hukum yang sama untuk kasus yang sama. Inilah doktrin kaum positivis, yang dikenali pula sebagai doktrin the supreme state of national law yang mengajarkan dan meyakini adanya status hukum yang mengatasi kekuaasaan dan otoritas lain, semisal otoritas politik. Inilah doktrin yang berkonsekuensi pada ajaran lebih lanjut agar setiap ahli hukum, khususnya yang tengah bertugas sebagai hakim, tidak menggunakan rujukan-rujukan normatif lain selain yang terbilang norma hukum guna menghukumi sesuatu perkara.

Hukum bertujuan untuk mewujudkan kepastian dalam hubungan antar manusia, yaitu menjamin prediktabilitas, dan juga bertujuan untuk mencegah jangan sampai hak yang terkuat yang berlaku. Apa yang telah diatur dalam hukum, itu harus ditaati dan menjadi putusan pengadilan. Artinya, tidak ada suatu perbuatan pun dapat dihukum kecuali atas kekuatan peraturan-perundang-undangan yang ada dan berlaku pada waktu itu. ${ }^{19}$

Beberapa asas yang terkandung dalam asas kepastian hukum adalah:

1. Asas legalitas, konstitusionalitas, dan supremasi hukum.

2. Asas undang-undang menetapkan berbagai perangkat aturan tentang cara pemerintah dan para pejabatnya melakukan tindakan pemerintahan.

\footnotetext{
${ }^{17}$ L.J. Van Apeldoorn, Pengantar Ilmu Hukum, Jakarta: PT. Pradnya Paramita, 1996 Cetakan Kedupuluhenam, Terjemahan: Mr. Oetarid Sadino.

${ }^{18}$ Mochtar Kusumaatmadja dan B. Arief Sidharta, Pengantar Ilmu Hukum, Suatu Pengenalan Pertama Ruang Lingkup Berlakunya Ilmu Hukum, Alumni, Bandung, 2000, hal. 52-53.

${ }^{19}$ Bernard Arief Sidharta, Op. Cit., hal. 190.
} 
3. Asas non-retroaktif perundang-undangan: sebelum mengikat, undangundang harus diumumkan secara layak.

4. Asas non-liquet: hakim tidak boleh menolak perkara yang dihadapkan kepadanya dengan alasan undang-undang tidak jelas atau tidak ada.

5. Asas peradilan bebas: objektif-imparsial dan adil-manusiawi.

6. Hak asasi manusia harus dirumuskan dan dijamin perlindungannya dalam Undang-Undang Dasar. ${ }^{20}$

Dalam konteks ini, yang dimaksud dengan kepastian hukum adalah adanya konsistensi peraturan dan penegakan hukum di Indonesia. Konsistensi peraturan ditunjukkan dengan adanya peraturan yang tidak saling bertentangan antara satu peraturan dengan peraturan yang lain, dan dapat dijadikan pedoman untuk suatu jangka waktu yang cukup. $^{21}$

Asas terakhir yang menjadi tujuan hukum adalah asas kemanfaatan. Asas ini merupakan asas yang mengiringi asas keadilan dan kepastian hukum dimana dalam melaksanakan kedua asas tersebut harus mempertimbangkan asas kemanfaatan dari hukum itu sendiri bagi masyarakat. Suatu peraturan yang tidak bermanfaat harus dihapus, direvisi, diamandemen dan/atau diganti dengan peraturan yang baru sebagai ius constitutum (hukum positif yang berlaku). ${ }^{22}$

Berdasarkan uraian di atas, disimpulkan bahwa keberhasilan penegakan hukum, ditentukan oleh seberapa jauh penegakan hukum tersebut telah mampu memenuhi 3 (tiga) asas, yakni asas keadilan, kepastian hukum, dan kemanfaatan hukum. Pemenuhan terhadap asas keadilan antara lain ditandai dari terlindunginya hak-hak masyarakat, termasuk hak pelanggar hukum, sesuai peraturan perundang-undangan. Asas kepastian hukum terpenuhi manakala hukum yang diwujudkan melalui peraturan perundangundangan, telah berlaku sama untuk setiap orang tanpa kecuali, dan peraturan perundangundangan telah bersifat konsisten, dimana tidak ada peraturan perundang-undangan yang saling bertentangan. Sementara pemenuhan asas kemanfaatan hukum, diukur dari seberapa

\footnotetext{
${ }^{20}$ Ibid.

${ }^{21}$ Budiman Ginting, "Kepastian Hukum Dan Implikasinya Terhadap Pertumbuhan Investasi Di Indonesia”, Pidato Pengukuhan Jabatan Guru Besar Tetap dalam Bidang Ilmu Hukum Investasi pada Fakultas Hukum, diucapkan di hadapan Rapat Terbuka Universitas Sumatera Utara, Medan, 2008.

${ }^{22}$ Bernard Arief Sidharta, Op. Cit.
} 
jauh peraturan yang tidak bermanfaat telah dihapus, direvisi, diamandemen dan/atau diganti dengan peraturan yang baru.

Berdasarkan uraian di atas, dapat ditarik pengertian bahwa di dalam negara yang berdasarkan atas hukum ((rechtsstaat), warga negara termasuk pelanggar hukum dihormati hak-haknya dan bersamaan kedudukannya di depan hukum.

Salah satu bentuk penghormatan terhadap hak-hak pelanggar hukum sebagai bagian dari warga negara, adalah diaturnya ketentuan tentang asas-asas hukum acara pidana nasional, yang memuliakan harkat dan martabat manusia, yang disangkakan, didakwakan dan/atau dinyatakan terbukti bersalah melakukan pelanggaran hukum pidana.

Asas-asas hukum acara pidana tersebut, termaktub di dalam Penjelasan Kitab Undang-Undang Hukum Acara Pidana (KUHAP), yang selengkapnya menyatakan sebagai berikut:

a. Perlakuan yang sama atas diri setiap orang di muka hukum dengan tidak mengadakan pembedaan perlakuan.

b. Penangkapan penahanan, penggeledahan dan penyitaan hanya dilakukan berdasarkan perintah tertulis oleh pejabat yang diberi wewenang oleh undang-undang dan hanya dalam hal dan dengan cara yang diatur dengan undang-undang.

c. Setiap orang yang disangka ditangkap, ditahan, dituntut dan atau dihadapkan di muka sidang, pengadilan, wajib dianggap tidak bersalah sampai adanya putusan pengadilan yang menyatakan kesalahannya dan memperoleh kekuatan hukum tetap.

d. Kepada seorang yang ditangkap ditahan, dituntut ataupun diadili tanpa alasan yang berdasarkan undang-undang dan karena kekeliruan mengenai orangnya atau hukum yang ditetapkan wajib diberi ganti kerugian dan rahabilitasi sejak tingkat penyidikan dan para pejabat penegak hukum yang dengan sengaja atau karena kelalaiannya menyebabkan asas hukum tersebut dilanggar, dituntut,dipidana dan atau dikenakan hukuman administrasi.

e. Peradilan yang harus dilakukan dengan cepat, sederhana dan biaya ringan serta bebas, jujur dan tidak memihak harus diterapkan secara konsekuen dalam seluruh tingkat peradilan. 
f. Setiap orang yang tersangkut perkara wajib diberi kesempatan memperoleh bantuan hukum yang semata-mata diberikan untuk melaksanakan kepentingan pembelaan dirinya.

g. Kepada seorang tersangka sejak saat dilakukan penangkapan dan atau penahanan selain wajib diberitahu dakwaan dan dasar hukum apa yang didakwakan kepadanya, juga wajib diberitahu haknya itu termasuk hak untuk menghubungi dan minta bantuan penasehat hukum.

h. Pengadilan pemeriksa perkara pidana dengan hadirnya terdakwa.

i. Sidang pemeriksan pengadilan adalah terbuka utnuk umum kecuali dalam hal yang diatur dalam undang-undang.

j. Pengawasan pelaksanaan putusan pengadilan dalam perkara pidana dilakukan oleh ketua pengadilan negeri yang bersangkutan

Diantara 10 (sepuluh) asas penyelenggaraan peradilan pidana Indonesia tersebut di atas, terdapat 1 (satu) asas yang penting karena berkaitan langsung dengan proses penyelesaian perkara pidana, yakni asas ke lima KUHAP, yang menggariskan bahwa "Peradilan yang harus dilakukan dengan cepat, sederhana dan biaya ringan serta bebas, jujur dan tidak memihak harus diterapkan secara konsekuen dalam seluruh tingkat peradilan".

Kemudian dalam penjelasan Pasal 2 ayat (4) Undang-Undang Kehakiman, dinyatakan bahwa yang dimaksud dengan "sederhana" adalah pemeriksaan dan penyelesaian perkara dilakukan dengan cara efesien dan efektif. Yang dimaksud dengan "biaya ringan" adalah biaya perkara yang dapat dijangkau oleh masyarakat. Namun demikian, asas sederhana, cepat, dan biaya ringan dalam pemeriksaan dan penyelesaian perkara di pengadilan tidak mengesampingkan ketelitian dan kecermatan dalam mencari kebenaran dan keadilan.

Berdasarkan asas tersebut, terlihat dengan jelas bahwa negara melalui kodifikasi hukum acara pidana nasional, ingin menjamin bahwa terhadap seluruh perkara pidana, terselenggara proses peradilan yang benar-benar cepat, sederhana dan biaya ringan serta bebas, jujur dan tidak memihak.

Masyarakat Indonesia yang mengalami krisis moral tersebut dapat dilihat dari semakin meningkatnya kejahatan dan meningkatnya pengangguran. Meningkatnya pengangguran sangat berpengaruh besar terhadap tingkat kesejahteraan masyarakat. Masyarakat dengan tingkat kesejahteraan yang rendah cenderung untuk tidak 
mempedulikan norma atau kaidahhukum yang berlaku. Melihat kondisi ini untuk memenuhi kebutuhan ada kecenderunganmenggunakan segala cara agar kebutuhan tersebut dapat terpenuhi dari cara-cara yangdigunakan ada yang melanggar dan tidak melanggar norma hukum.

Berbagai macam tindak pidanapun sering bermunculan di masyarakat. Ada yang tergolong tindak pidanaberat dan ada jugayang tergolong tindak pidana ringan.Beberapa contoh tindak pidana ringan yang terjadi di Indonesia, yang kerugiannya sangat kecil,diselesaikan dengan standar pemeriksaan perkara biasa, bertentangan dengan asas peradilan cepat, sederhana, dan biaya ringan.

Untuk menjamin terselenggaranya proses peradilan yang cepat, KUHAP mengatur sejumlah ketentuan, antara lain mengenai batas waktu penahanan. Dengan adanya penetapan batas waktu penahanan, proses peradilan mulai dari penyidikan, penuntutan, pemeriksaan dan penjatuhan putusan oleh sidang pengadilan, diharapkan dapat berlangsung secara cepat, sederhana dan biaya ringan.

Ikhwal mengenai penahanan, diatur secara khusus di dalam Bab V Bagian Kedua yang meliputi Pasal 20 sampai dengan Pasal 31. Pembentuk KUHAP memberikan perhatian khusus terhadap masalah penahanan ini, terbukti dengan banyaknya jumlah pasal yang mengaturnya, yaitu terdiri dari 12 (dua belas) pasal dan 43 (empat puluh tiga) ayat.

Pasal 20 mengatur kewenangan melakukan penahanan pada setiap tingkat pemeriksaan. Pasal 21 mengatur penahanan yang merupakan kewenangan penuntut umum, dan alasan penahanan lanjutan bila penahanan dimaksud dilakukan. Pasal 22 mengatur jenis penahanan. Pasal 23 mengatur pengalihan jenis penahanan. Pasal 24 sampai dengan Pasal 28 mengatur lamanya penahanan dapat dilakukan. Pasal 29 mengatur perpanjangan jangka waktu penahanan karena alasan khusus. Pasal 30 mengatur hak tersangka atau terdakwa untuk meminta ganti rugi karena penahanan yang tidak sah. Pasal 31 mengatur penangguhan penahanan dengan jaminan uang atau orang atau tanpa jaminan tersebut.

Menurut ketentuan Pasal 24 KUHAP, batas waktu penahanan dalam tahap penyidikan adalah 60 (enam puluh) hari. Meskipun proses penyidikan belum selesai setelah waktu 60 (enam puluh) hari tersebut, maka penyidik harus sudah mengeluarkan tersangka dari tahanan demi hukum.

Pada tahapan selanjutnya yakni penuntutan oleh jaksa penuntut umum. Menurut ketentuan Pasal 25 KUHAP, batas waktu penahanan dalam proses penuntutan adalah 50 (lima puluh) hari. Meskipun proses penuntutan belum selesai, setelah waktu 50 (lima 
puluh) hari tersebut, maka jaksa penuntut umum harus sudah mengeluarkan tersangka dari tahanan demi hukum.

Dalam tahapan kemudian, yakni tahap pemeriksaan di sidang pengadilan, hakim pengadilan negeri yang mengadili perkara menurut ketentuan Pasal 26 KUHAP, memiliki batas waktu penahanan terhadap seorang terdakwa adalah 90 (sembilan puluh) hari. Sama halnya dengan batas waktu penahanan pada tahapa penyidikan dan penuntutan, walaupun setelah waktu 90 (sembilan puluh) hari tersebut, perkara belum diputus, terdakwa harus sudah dikeluarkan dari tahanan demi hukum.

Setelah perkara diputus oleh majelis hakim Pengadilan Negeri, maka terdakwa dapat mengajukan banding ke Pengadilan Tinggi. Lamanya waktu yang diperbolehkan untuk Hakim Pengadilan Tinggi yang mengadili perkara untuk menahan seorang terdakwa, menurut ketentuan Pasal 27 KUHAP, adalah 90 (sembilan puluh) hari. Setelah waktu 90 (sembilan puluh) hari, walaupun perkara tersebut belum diputus, terdakwa harus sudah dikeluarkan dari tahanan demi hukum.

Terhadap putusan Pengadilan Tinggi, terdakwa juga dapat mengajukan upaya hukum berupa upaya hukum kasasi. Menurut ketentuan Pasal 28 KUHAP, Hakim Mahkamah Agung berwenang menahan terdakwa selama 110 (seratus sepuluh) hari. Setelah waktu tersebut, walaupun perkara belum diputus, terdakwa harus sudah dikeluarkan dari tahanan demi hukum.

Berdasarkan paparan di atas, dapat dilihat dengan jelas bahwa penetapan batas waktu penahanan, telah menjadi instrumen penting untuk mendorong penegak hukum pada masing-masing tahapan proses peradilan pidana, agar bekerja maksimal sedemikian sehingga proses perkara telah dapat selesai sebelum batas waktu penahanan habis.

Dengan demikian, ketentuan KUHAP yang mengatur tentang batas waktu penahanan, telah menjadi sarana hukum untuk mencapai asas peradilan yang cepat dan sederhana, sebagaimana diamanatkan di dalam asas-asas hukum acara pidana Indonesia.

Dengan kata lain, terhadap tersangka dan terdakwa yang dikenakan penahanan, ketentuan mengenai batas waktu penahanan adalah sarana hukum yang efektif untuk menjamin bahwa kehilangan hak kemerdekaan akibat penahanan, benar-benar termanfaatkan sedemikian rupa, sehingga pelanggar hukum tersebut memperoleh penanganan perkara pidananya dengan cepat dan sederhana.

Persoalan sebaliknya terjadi terhadap tersangka atau terdakwa yang tidak dikenakan penahanan. Tidak ditemukan ketentuan KUHAP yang mengatur tentang batas 
waktu penyelesaian perkara pidana, terhadap tersangka atau terdakwa yang tidak mengalami penahanan. Oleh karena itu, tidaklah mengherankan manakala penanganan perkara pidana dimana tersangka atau terdakwanya tidak ditahan, dapat berjalan demikian lama dan berlarut-larut.

Pemeriksaan di sidang Pengadilan tingkat pertama, pengiriman berkas ke tingkat banding, pemeriksaan di tingkat banding, pengiriman berkas ke tingkat kasasi, pemeriksaan oleh hakim kasasi, pengiriman putusan dari Mahkamah Agung ke pengadilan tingkat pertama dan Kejaksaan, memerlukan waktu bahkan bisa sampai bertahun-tahun, karena ketiadaan ketentuan yang mengatur tentang batas waktu penyelesaian perkara.

Ketiadaan pengaturan tersebut, pada sisi lain juga dapat dimanfaatkan oleh tersangka atau terdakwa, atau mafia hukum untuk memperlambat penyelesaian sebuah perkara pidana, sedemikian sehingga pada gilirannya menciderai rasa keadilan dan kepastian hukum di tengah masyarakat.

Berdasarkan uraian di atas, disimpulkan bahwa dalam kaitan dengan pemenuhan asas peradilan yang cepat, sederhana dan biaya ringan, terdapat norma yang kosong (vacuum of norm) di dalam KUHAP yang mengatur tentang batas waktu penyelesaian perkara pidana terhadap tersangka atau terdakwa yang tidak dikenakan penahanan. Kekosongan norma hukum tersebut sangat berpotensi melemahkan penegakan hukum karena menimbulkan ketidak-pastian hukum, ketidak-adilan hukum, dan ketidakmanfaatan hukum di tengah masyarakat.

\section{B. Perumusan Masalah}

Berdasarkan latar belakang yang dipaparkan di atas, maka dirumuskan pokok permasalahan penelitian ini sebagai berikut:

1. Bagaimana pengaturan mengenai penyelesaian perkara pidana di dalam KUHAP sehingga mampu memenuhi asas peradilan yang cepat, sederhana dan biaya ringan?;

2. Bagaimanakah Implementasinya penyelesaian perkara pidana mampu memenuhi asas peradilan yang cepat, sederhana dan biaya ringan?

3. Bagaimana pengaturan mengenai penyelesaian perkara pidana yang sebaiknya diterapkan di dalam KUHAP yang akan datang?.

\section{Metode Penelitian}




\section{Metode Pendekatan}

Mengingat penelitian ini menitik beratkan pada pencarian data sekunder, sedangkan data primer hanyalah lebih bersifat menunjang, maka penelitian ini lebih bersifat Yuridis Normatif, yaitu pendekatan yang dimulai dengan mengadakan analisis terhadap peraturanperaturan hukum yang berlaku.

Penelitian normatif diambil sebagai pendekatan utama dalam penelitian ini karena yang menjadi perhatian utama adalah ketentuan perundang-undangan yang mengatur mengenai asas peradilan pidana Indonesia.

2. Spesifikasi Penelitian

Spesifikasi penelitian lebih bersifat deskriptif analisis, yaitu penelitian ini sifatnya adalah menjelaskan ketentuan perundang-undangan yang mengatur mengenai asas peradilan pidana Indonesia.

3. Sumber Data

Sumber data yang diguakan hanyalah data sekunder (penelitian kepustakaan) yang ditelaah dari bahan hukum primer, sekunder dan bahan hukum tersier. Objek penelitian yang berupa penelitian terhadap makalah, surat kabar, tabloid, peraturan perundangundangan yang dijadikan sebagai hukum positif yang ada relevansinya dengan judul yang penulis bahas.

\section{Analisis Data}

Data-data sekunder yang diperoleh dari hasil penelitian kepustakaan, kemudian dikumpulkan, disusun, diolah dan dipisah-pisahkan ke dalam bagian-bagian tertentu, untuk seterusnya dianalisis.

Analisis yang digunakan dalam penelitian ini bersifat analisis kualitatif, yaitu dengan menelaah berbagai peraturan hukum yang berlaku, teori-teori pendapat ahli atau sarjana hukum yang kemudian dihubungkan dengan judul yang dibahas.

\section{Pengaturan asas peradilan cepat, sederhana dan biaya ringan dalam hukum acara pidana indonesia}

1. Pengaturan Mengenai Penyelesaian Perkara Pidana di Dalam KUHAP Sehingga Mampu Memenuhi Asas Peradilan yang Cepat, Sederhana dan Biaya Ringan

Sebagaimana telah dikemukakan sebelumnya, bahwa salah satu bentuk penghormatan terhadap hak-hak pelanggar hukum sebagai bagian dari warga negara, adalah diaturnya ketentuan tentang asas-asas hukum acara pidana nasional, yang 
memuliakan harkat dan martabat manusia yang disangkakan, didakwakan dan/atau dinyatakan terbukti bersalah melakukan pelanggaran hukum pidana.

Asas-asas hukum acara pidana tersebut, termaktub di dalam Penjelasan KUHAP, yang selengkapnya menyatakan sebagai berikut:

a. Perlakuan yang sama atas diri setiap orang di muka hukum dengan tidak mengadakan pembedaan perlakuan.

b. Penangkapan penahanan, penggeledahan dan penyitaan hanya dilakukan berdasarkan perintah tertulis oleh pejabat yang diberi wewenang oleh undang-undang dan hanya dalam hal dan dengan cara yang diatur dengan undang-undang.

c. Setiap orang yang disangka ditangkap, ditahan, dituntut dan atau dihadapkan di muka sidang, pengadilan, wajib dianggap tidak bersalah sampai adanya putusan pengadilan yang menyatakan kesalahannya dan memperoleh kekuatan hukum tetap.

d. Kepada seorang yang ditangkap ditahan, dituntut ataupun diadili tanpa alasan yang berdasarkan undang-undang dan karena kekeliruan mengenai orangnya atau hukum yang ditetapkan wajib diberi ganti kerugian dan rahabilitasi sejak tingkat penyidikan dan para pejabat penegak hukum yang dengan sengaja atau karena kelalaiannya menyebabkan asas hukum tersebut dilanggar, dituntut,dipidana dan atau dikenakan hukuman administrasi.

e. Peradilan yang harus dilakukan dengan cepat, sederhana dan biaya ringan serta bebas, jujur dan tidak memihak harus diterapkan secara konsekuen dalam seluruh tingkat peradilan.

f. Setiap orang yang tersangkut perkara wajib diberi kesempatan memperoleh bantuan hukum yang semata-mata diberikan untuk melaksanakan kepentingan pembelaan dirinya.

g. Kepada seorang tersangka sejak saat dilakukan penangkapan dan atau penahanan selain wajib diberitahu dakwaan dan dasar hukum apa yang didakwakan kepadanya, juga wajib diberitahu haknya itu termasuk hak untuk menghubungi dan minta bantuan penasehat hukum.

h. Pengadilan pemeriksa perkara pidana dengan hadirnya terdakwa.

i. Sidang pemeriksan pengadilan adalah terbuka utnuk umum kecuali dalam hal yang diatur dalam undang-undang. 
j. Pengawasan pelaksanaan putusan pengadilan dalam perkara pidana dilakukan oleh ketua pengadilan negeri yang bersangkutan

Diantara 10 (sepuluh) asas penyelenggaraan peradilan pidana Indonesia tersebut di atas, terdapat 1 (satu) asas yang penting karena berkaitan langsung dengan proses penyelesaian perkara pidana, yakni asas ke lima KUHAP, yang menggariskan bahwa "Peradilan yang harus dilakukan dengan cepat, sederhana dan biaya ringan serta bebas, jujur dan tidak memihak harus diterapkan secara konsekuen dalam seluruh tingkat peradilan".

Ketentuan mengenai asas peradilan cepat, sederhana, dan biaya ringan tersebut, kemudian ditegaskan kembali dalam ketentuan Pasal KUHAP yang mengatur tentang hakhak tersangka/terdakwa. Sebagaimana diuraikan terdahulu bahwa Hak-hak tersangka dan terdakwa tersebut, termaktub di dalam Pasal 50 sampai dengan Pasal 68 KUHAP, yang pada pokoknya mengatur mengenai 19 (sembilan belas) hak tersangka dan terdakwa, yang dijamin oleh KUHAP untuk dilaksanakan secara penuh tanpa dapat dikurangi sedikitpun.

Hak-hak dimaksud meliputi hak untuk segera mendapat pemeriksaan oleh penyidik dan selanjutnya segera diajukan kepada Penuntut Umum, dimajukan ke pengadilan, dan segera diadili oleh pengadilan, hak untuk diberitahukan dengan tentang apa yang disangkakan dan didakwakan kepadanya pada waktu pemeriksaan dimulai, hak memberikan keterangan secara bebas kepada penyidik atau hakim, hak untuk setiap waktu mendapat bantuan juru bahasa, hak mendapatkan bantuan hukum dari seseorang atau lebih penasihat hukum selama dalam waktu dan pada setiap tingkat pemeriksaan, hak untuk mendapat dan memilih sendiri penasihat hukum, hak untuk mendapat penasihat hukum secara cuma-cuma, bagi tersangka atau terdakwa yang diancam pidana mati atau pidana lima belas tahun ataupun lebih, atau yang tidak mampu yang diancam dengan lima tahun atau lebih yang tidak mempunyai penasihat hukum sendiri, hak menghubungi penasihat hukumnya, hak menghubungi dan menerima kunjungan dokter pribadinya untuk kepentingan kesehatan, bagi yang ditahan, hak diberitahukan tentang penahanan atas dirinya, kepada keluarganya atau orang lain yang serumah dengannya, ataupun orang lain yang bantuannya dibutuhkan oleh tersangka untuk mendapatkan bantuan hukum atau jaminan bagi penangguhannya, apabila ia ditahan, hak menghubungi dan menerima kunjungan dari pihak keluarga atau lainnya guna mendapatkan bantuan hukum, hak secara langsung atau dengan perantaraan penasihat hukumnya menghubungi dan menerima 
kunjungan sanak keluarganya dalam hal yang tidak ada hubungannya dengan perkara tersangka atau terdakwa untuk kepentingan pekerjaan atau untuk kepentingan kekeluargaan, hak mengirim dan menerima surat kepada atau dari penasihat hukumnya, menerima surat dari sanak keluarganya setiap kali yang diperlukan olehnya, hak untuk menghubungi dan menerima kunjungan dari rohaniawan hak untuk diadili di sidang pengadilan yang terbuka untuk umum, hak untuk mengusahakan dan mengajukan saksi atau seseorang yang memiliki keahlian khusus guna memberikan keterangan yang menguntungkan bagi dirinya, berhak untuk tidak dibebani kewajiban pembuktian, hak untuk minta banding terhadap putusan pengadilan tingkat pertama kecuali terhadap putusan bebas, lepas dari segala tuntutan hukum yang menyangkut masalah kurang tepatnya penerapan hukum dan putusan pengadilan dalam acara cepat, dan hak menuntut ganti kerugian dan rehabilitasi.

Perumusan mengenai hak-hak tersangka dan terdakwa di dalam KUHAP sebagaimana diuraikan di atas, secara jelas dapat dipandang sebagai perwujudan yang nyata dari tujuan penegakan hukum, yang ingin dicapai oleh Indonesia sebagai negara hukum (rechstaat), yakni terpenuhinya asas keadilan dan kebenaran, dimana di dalam memperoleh keadilan dan kebenaran tersebut hak-hak pelanggar hukum, sebagai bagian dari hak asasi manusia, harus dihormati, dipenuhi dan dilindungi.

Di samping itu, apabila dicermati kesembilan belas hak tersangka atau terdakwa tersebut di atas, memiliki kaitan dengan penerapan asas KUHAP tentang peradilan yang dilakukan dengan cepat, sederhana dan berbiaya ringan.

Namun demikian, terdapat satu hak tersangka/terdakwa yang berkaitan langsung dengan penerapan asas peradilan yang dilakukan dengan cepat, sederhana dan berbiaya ringan. Pasal dimaksud adalah Pasal 50 KUHAP, yang menggariskan bahwa "Tersangka berhak segera mendapat pemeriksaan oleh penyidik dan selanjutnya segera diajukan kepada Penuntut Umum, dimajukan ke pengadilan, dan segera diadili oleh pengadilan”.

Di dalam Penjelasan KUHAP, diterangkan maksud dari ketentuan Pasal 50, bahwa "Diberikannya hak kepada tersangka atau terdakwa dalam pasal ini adalah untuk menjauhkan kemungkinan terkatung-katungnya nasib seorang yang disangka melakukan tindak pidana terutama mereka yang dikenakan penahanan, jangan sampai lama tidak mendapat pemeriksaan sehingga dirasakan tidak adanya kepastian hukum, adanya perlakuan sewenang-wenang dan tidak wajar. Selain itu juga untuk mewujudkan peradilan yang dilakukan dengan sederhana, cepat dan biaya ringan". 
Berdasarkan penjelasan Pasal 50 KUHAP tersebut di atas, terlihat dengan nyata bahwa penyegeraan proses penanganan perkara pidana, merupakan perintah KUHAP yang harus dipatuhi oleh penyidik, penuntut umum dan pengadilan. Adapun tujuan dari penyegeraan penanganan perkara, adalah untuk melindungi hak-hak tersangka/terdakwa, agar tidak berlarut-larut atau terkatung-katung, dalam memperoleh keadilan dan kepastian hukum.

Dengan demikian, dapat dirasakan betapa penting dan strategisnya kehadiran dan eksistensi KUHAP dalam penegakan hukum. Terkait dengan hal itu, Komisi Hukum Nasional Republik Indonesia (KHN RI), mengung-kapkan bahwa:

Sejak awal keberadaannya, hukum pidana dan hukum acara pidana, diperuntukakan melindungi masyarakat dari kesewenang-wenangan penguasa. Dalam hal ini J.E. Sahetapy, meminjam konsep Jerome H. Skolnick mengatakan bahwa "criminal procedure is intended to control authorities, not criminals".

Pendapat senada disampaikan oleh Mardjono Reksodiputro, yang mengatakan bahwa:

Fungsi dari Undang-Undang Acara Pidana adalah untuk membatasi kekuasaan negara dalam bertindak terhadap warga masyarakat yang terlibat dalam proses peradilan pidana. Namun di sisi lain, hukum acara pidana juga memberikan kewenangankewenangan tertentu kepada negara melalui penegak hukum untuk melakukan tindakantindakan yang dapat melanggar hak asasi warganya. ${ }^{23}$

Terhadap kewenangan penegak hukum yang dapat menimbulkan pelanggaran hak tersangka/terdakwa tersebut, Loebby Loqman seperti dikuti KHN RI, berpendapat sebagai berikut:

Hukum acara pidana seharusnya mampu menjaga batas antara kewenangan upaya paksa aparat penegak hukum (penangkapan, pena-hanan, penyitaan, penggeledahan) dengan perlindungan hak tersangka, sehingga dapat mencerminkan hukum acara pidana dalam lingkup suatu negara hukum. Oleh karenanya dalam hukum acara pidana, harus ada suatu batasan yang tegas, terutama berkaitan dengan pembatasan hak asasi tersangka, sebab dilakukannya upaya paksa, maka dengan sendirinya telah terjadi pelanggaran hak asasi seseorang. Penggunaan upaya paksa di lain pihak tidak lain dilakukan untuk mencari bukti bahwa seseorang telah melakukan suatu tindak pidana.

\footnotetext{
${ }^{23}$ Mardjono Reksodiputro, Buku Ketiga, Op. Cit., hal. 25.
} 
Selanjutnya, asas peradilan yang dilakukan dengan sederhana, cepat dan berbiaya ringan, juga diatur di dalam Undang-Undang Nomor 48 Tahun 2009 tentang Kekuasaan Kehakiman (selanjutnya disebut Undang-Undang Kekuasaan Kehakiman). Di dalam Pasal 2 ayat (4) Undang-Undang Kekuasaan Kehakiman, ditegaskan bahwa "Peradilan dilakukan dengan sederhana, cepat, dan biaya ringan".

Kemudian dalam penjelasan Pasal 2 ayat (4) dimaksud, dinyatakan bahwa yang dimaksud dengan "sederhana" adalah pemeriksaan dan penyelesaian perkara dilakukan dengan cara efesien dan efektif. Yang dimaksud dengan "biaya ringan" adalah biaya perkara yang dapat dijangkau oleh masyarakat. Namun demikian, asas sederhana, cepat, dan biaya ringan dalam pemeriksaan dan penyelesaian perkara di pengadilan tidak mengesampingkan ketelitian dan kecermatan dalam mencari kebenaran dan keadilan.

Dengan menerapkan asas peradilan yang dilakukan dengan sederhana dan biaya ringan dalam penyelesaian perkara perdata diharapkan proses penyelesaian perkara tersebut tidak berlarut-larut dan dapat diselesaikan dalam jangka waktu yang tidak terlalu lama, sehingga biaya yang dikeluarkan oleh para pihak tidak terlalu tinggi.

Kemudian dari pada itu, untuk menjamin terselenggaranya proses peradilan yang cepat, dan menjauhkan kemungkinan terkatung-katungnya nasib seorang yang disangka melakukan tindak pidana terutama mereka yang dikenakan penahanan, jangan sampai lama tidak mendapat pemeriksaan sehingga dirasakan tidak adanya kepastian hukum, adanya perlakuan sewenang-wenang dan tidak wajar, KUHAP mengatur sejumlah ketentuan, antara lain mengenai batas waktu penahanan.

Dengan adanya penetapan batas waktu penahanan, proses peradilan mulai dari penyidikan, penuntutan, pemeriksaan dan penjatuhan putusan oleh sidang pengadilan, diharapkan dapat berlangsung secara cepat, sederhana dan biaya ringan.

Ikhwal mengenai penahanan, diatur secara khusus di dalam Bab V Bagian Kedua yang meliputi Pasal 20 sampai dengan Pasal 31. Pembentuk KUHAP memberikan perhatian khusus terhadap masalah penahanan ini, terbukti dengan banyaknya jumlah pasal yang mengaturnya, yaitu terdiri dari 12 (dua belas) pasal dan 43 (empat puluh tiga) ayat.

Pasal 20 mengatur kewenangan melakukan penahanan pada setiap tingkat pemeriksaan. Pasal 21 mengatur penahanan yang merupakan kewenangan penuntut umum, dan alasan penahanan lanjutan bila penahanan dimaksud dilakukan. Pasal 22 mengatur jenis penahanan. Pasal 23 mengatur pengalihan jenis penahanan. Pasal 24 sampai dengan Pasal 28 mengatur lamanya penahanan dapat dilakukan. Pasal 29 mengatur perpanjangan 
jangka waktu penahanan karena alasan khusus. Pasal 30 mengatur hak tersangka atau terdakwa untuk meminta ganti rugi karena penahanan yang tidak sah. Pasal 31 mengatur penangguhan penahanan dengan jaminan uang atau orang atau tanpa jaminan tersebut.

Menurut ketentuan Pasal 24 KUHAP, batas waktu penahanan dalam tahap penyidikan adalah 60 (enam puluh) hari. Meskipun proses penyidikan belum selesai setelah waktu 60 (enam puluh) hari tersebut, maka penyidik harus sudah mengeluarkan tersangka dari tahanan demi hukum.

Pada tahapan selanjutnya yakni penuntutan oleh jaksa penuntut umum. Menurut ketentuan Pasal 25 KUHAP, batas waktu penahanan dalam proses penuntutan adalah 50 (lima puluh) hari. Meskipun proses penuntutan belum selesai, setelah waktu 50 (lima puluh) hari tersebut, maka jaksa penuntut umum harus sudah mengeluarkan tersangka dari tahanan demi hukum.

Dalam tahapan kemudian, yakni tahap pemeriksaan di sidang pengadilan, hakim pengadilan negeri yang mengadili perkara menurut ketentuan Pasal 26 KUHAP, memiliki batas waktu penahanan terhadap seorang terdakwa adalah 90 (sembilan puluh) hari. Sama halnya dengan batas waktu penahanan pada tahapa penyidikan dan penuntutan, walaupun setelah waktu 90 (sembilan puluh) hari tersebut, perkara belum diputus, terdakwa harus sudah dikeluarkan dari tahanan demi hukum.

Setelah perkara diputus oleh majelis hakim Pengadilan Negeri, maka terdakwa dapat mengajukan banding ke Pengadilan Tinggi. Lamanya waktu yang diperbolehkan untuk Hakim Pengadilan Tinggi yang mengadili perkara untuk menahan seorang terdakwa, menurut ketentuan Pasal 27 KUHAP, adalah 90 (sembilan puluh) hari. Setelah waktu 90 (sembilan puluh) hari, walaupun perkara tersebut belum diputus, terdakwa harus sudah dikeluarkan dari tahanan demi hukum.

Terhadap putusan Pengadilan Tinggi, terdakwa juga dapat mengajukan upaya hukum berupa upaya hukum kasasi. Menurut ketentuan Pasal 28 KUHAP, Hakim Mahkamah Agung berwenang menahan terdakwa selama 110 (seratus sepuluh) hari. Setelah waktu tersebut, walaupun perkara belum diputus, terdakwa harus sudah dikeluarkan dari tahanan demi hukum.

Selanjutnya, diatur pula ketentuan khusus yang memungkinkan perpanjangan waktu penahanan lebih lama dari ketentuan Pasal 20 sampai dengan Pasal 28, yang berlaku khusus bagi tersangka atau terdakwa menderita gangguan fisik atau mental yang berat, 
yang dibuktikan dengan surat keterangan dokter, atau perkara yang sedang diperiksa diancam dengan pidana penjara sembilan tahun atau lebih.

Ketentuan tersebut, termaktub di dalam Pasal 29 KUHAP, yang selengkapnya mengatur bahwa:

Pasal 29

(1) Dikecualikan dan jangka waktu penahanan sebagahnana tersebut pada Pasal 24, Pasal 25, Pasal 26, Pasal 27 dan Pasal 28, guna kepentingan pemeriksaan, penahanan terhadap tersangka atau terdakwa dapat diperpanjang berdasar alasan yang patut dan tidak dapat dihindarkan karena:

a. tersangka atau terdakwa menderita gangguan fisik atau mental yang berat, yang dibuktikan dengan surat keterangan dokter, atau

b. perkara yang sedang diperiksa diancam dengan pidana penjara sembilan tahun atau lebih.

(2) Perpanjangan tersebut pada ayat (1) diberikan untuk paling lama tiga puluh hari dan dalam hal penahanan tersebut masih diperlukan, dapat diperpanjang lagi untuk paling lama tiga puluh hari.

(3) Perpanjangan penahanan tersebut átas dasar permintaan dan Iaporan pemeriksaan dalam tingkat:

a. penyidikan dan penuntutan diberikan oleh ketua pengadilan negeri;

b. pemeriksaan di pengadilan negeri diberikan oIeh ketua pengadilan tinggi;

c. pemeriksaan banding diberikan oleh Mahkamah Agung;

d. pemeriksaan kasasi diberikan oleh Ketua Mahkamah Agung.

(4) Penggunaan kewenangan perpanjangan penahanan oleh pejabat tersebut pada ayat (3) dilakukan secara bertahap dan dengan penuh tanggung jawab.

(5) Ketentuan sebagaimana tersebut pada ayat (2) tidak menutup kemungkinan dikeluarkannya tersangka atau terdakwa dari tahanan sebelum berakhir waktu penahanan tersebut, jika kepentingan pemeriksaan sudah dipenuhi.

(6) Setelah waktu enam puluh hari, walaupun perkara tersebut belum selesai diperiksa atau belum diputus, tersangka atau terdakwa harus sudah dikeluarkan dari tahanan demi hukum. 
(7) Terhadap perpanjangan penahanan tersebut pada ayat (2) tersangka atau terdakwa dapat mengajukan keberatan dalam tingkat:

a. penyidikan dan penuntutan kepada ketua pengadilan tinggi;

b. pemeriksaan pengadilan negeri dan pemeriksaan banding kepada Ketua Mahkamah Agung.

\begin{tabular}{|c|c|c|c|c|c|}
\hline \multirow[b]{2}{*}{ No. } & \multirow[b]{2}{*}{$\begin{array}{c}\text { Tahapan } \\
\text { Perkara } \\
\text { Pidana }\end{array}$} & \multicolumn{2}{|c|}{ Pasal 20 sd 28} & \multicolumn{2}{|c|}{ Pasal 29} \\
\hline & & $\begin{array}{c}\text { Batas } \\
\text { Waktu } \\
\text { Penahanan }\end{array}$ & $\begin{array}{l}\text { Pasal yang } \\
\text { Mengatur }\end{array}$ & $\begin{array}{c}\text { Batas } \\
\text { Waktu } \\
\text { Penahanan }\end{array}$ & $\begin{array}{l}\text { Pasal yang } \\
\text { Mengatur }\end{array}$ \\
\hline 1. & Penyidikan & 60 hari & $\begin{array}{l}24 \text { ayat (1), } \\
\text { (2) dan (4) }\end{array}$ & 120 hari & $\begin{array}{l}24 \text { ayat }(1),(2) \\
\text { dan (4) }\end{array}$ \\
\hline 2. & Penuntutan & 50 hari & $\begin{array}{l}25 \text { ayat (1), } \\
\text { (2) dan (4) }\end{array}$ & 110 hari & $\begin{array}{l}25 \text { ayat (1), (2) } \\
\text { dan (4) }\end{array}$ \\
\hline 3. & $\begin{array}{l}\text { Pemeriksaan di } \\
\text { sidang } \\
\text { Pengadilan }\end{array}$ & 90 hari & $\begin{array}{l}26 \text { ayat (1), } \\
\text { (2) dan (4) }\end{array}$ & 150 hari & $\begin{array}{l}26 \text { ayat }(1),(2) \\
\text { dan }(4)\end{array}$ \\
\hline 4. & $\begin{array}{l}\text { Pemeriksaan } \\
\text { Banding }\end{array}$ & 90 hari & $\begin{array}{l}27 \text { ayat (1), } \\
\text { (2) dan (4) }\end{array}$ & 150 hari & $\begin{array}{l}27 \text { ayat }(1),(2) \\
\text { dan (4) }\end{array}$ \\
\hline 5. & $\begin{array}{l}\text { Pemeriksaan } \\
\text { Kasasi }\end{array}$ & 110 hari & $\begin{array}{l}28 \text { ayat (1), } \\
\text { (2) dan (4) }\end{array}$ & 170 hari & $\begin{array}{l}28 \text { ayat }(1),(2) \\
\text { dan (4) }\end{array}$ \\
\hline \multicolumn{2}{|c|}{$\begin{array}{l}\text { Total Masa } \\
\text { Penahanan } \\
\text { Maksimum }\end{array}$} & 400 hari & & 700 hari & \\
\hline
\end{tabular}

2. Implementasi Penyelesaian Perkara Pidana Mampu Memenuhi Asas Peradilan yang Cepat,Sederhana dan Biaya Ringan.

Untuk memudahkan pemahaman, ketentuan yang mengatur tentang penahanan, sebagaimana diatur di dalam Pasal 20 sampai dengan Pasal 29 KUHAP dapat ditabulasikan, sebagaimana dapat dilihat pada Tabel di bawah ini.

Berdasarkan tabulasi di atas, dapat disimpulkan bahwa dihitung sejak proses penyidikan sampai dengan putusan kasasi, atau sejak tersangka ditahan sampai suatu putusan memiliki kekuatan hukum tetap, suatu perkara pidana harus dapat diselesaikan oleh penyidik, penuntut umum, majelis hakim tingkat pertama, majelis hakim banding, dan majelis hakim kasasi paling lambat dalam jangka waktu 400 (empat ratus) hari.

Total masa penahanan maksimum tersebut, tidak berlaku bagi tersangka atau terdakwa yang menderita gangguan fisik atau mental yang berat, yang dibuktikan dengan 
surat keterangan dokter, atau perkara yang sedang diperiksa diancam dengan pidana penjara sembilan tahun atau lebih. Dengan penambahan masa penahanan maksimum 60 (enam puluh) hari pada masing-masing tingkatan penyidikan, tersangka/terdakwa dengan kriteria khusus di atas, harus menunggu lebih lama di dalam tahanan sampai kasusnya memiliki kekuatan hukum tetap, yakni selama 700 (tujuh ratus) hari.

Dengan adanya batas waktu maksimum seseorang boleh dikenakan penahanan, maka penegak hukum pada masing-masing tingkatan akan dipacu untuk bekerja secara efektif menyelesaikan perkara pidana yang menjadi kewajibannya. Resiko yang harus dihadapi oleh penegak hukum dimaksud, manakala penanganan perkara tidak dapat diselesaikan sebelum batas waktu penahanan adalah dikeluarkannya tersangka/terdakwa dari tahanan demi hukum.

Dengan demikian, pada satu sisi batas waktu penahanan berfungsi melindungi hak tersangka/terdakwa, agar nasibnya menjadi tidak terkatung-katung karena lama tidak mendapat pemeriksaan, lambat memperoleh kepastian hukum, dan menghindarkan tersangka/terdakwa dari kemungkinan mendapatkan perlakuan sewenang-wenang dan tidak wajar. Pada sisi lain, batas waktu penahanan merupakan instrumen untuk menjamin terselenggaranya peradilan yang dilakukan secara cepat, sederhana, dan berbiaya ringan.

Dengan kata lain, terhadap tersangka dan terdakwa yang dikenakan penahanan, ketentuan mengenai batas waktu penahanan adalah sarana hukum yang efektif untuk menjamin bahwa kehilangan hak kemerdekaan akibat penahanan, benar-benar termanfaatkan sedemikian rupa sehingga pelanggar hukum tersebut memperoleh penanganan perkara pidananya dengan cepat dan sederhana.

Jaminan terselenggaranya peradilan yang cepat, sederhana dan berbiaya ringan akibat adanya ketentuan KUHAP yang mengatur tentang penetapan batas penahanan tersebut, tidak terjadi manakala sejak penyidikan tersangka/terdakwa tidak pernah dikenakan penahanan, dialihkan jenis penahanannya, atau dikeluarkan dari tahanan demi hukum karena penanganan perkara pidana telah melewati batas waktu penahanan yang dimungkinkan oleh KUHAP.

Mengenai tidak dikenakannya penahanan terhadap tersangka/terdakwa sejak dari proses penyidikan, dimungkinkan oleh KUHAP. Sebagaimana telah dikemukakan sebelumnya bahwa penyidik, penuntut umum, dan pengadilan memiliki kewenangan diskresi untuk melakukan atau tidak melakukan penahanan terhadap tersangka/terdakwa. Kewenangan tersebut diatur di dalam Pasal 21 ayat (1) KUHAP, yang selengkapnya 
menggariskan bahwa "Perintah penahanan atau penahanan lanjutan dilakukan terhadap seorang tersangka atau terdakwa yang diduga keras melakukan tindak pidana berdasarkan bukti yang cukup, dalam hal adanya keadaan yang menimbulkan kekhawatiran bahwa tersangka atau terdakwa akan melarikan diri, merusak atau menghilangkan barang bukti dan atau mengulangi tindak pidana".

Berdasarkan ketentuan Pasal 21 ayat (1) KUHAP di atas, jelas bahwa sepanjang penegak hukum yang menangani perkara pidana pada masing-masing tingkatan merasa bahwa tersangka atau terdakwa tidak akan melarikan diri, merusak atau menghilangkan barang bukti dan atau mengulangi tindak pidana, maka kepada si tersangka atau terdakwa itu tidak perlu dikenakan penahanan.

Dalam hal tersangka atau terdakwa tidak ditahan, muncul persoalan berkaitan dengan terselenggaranya asas KUHAP tentang peradilan yang dilakukan dengan cepat, sederhana dan berbiaya ringan. Persoalan tersebut timbul karena tidak adanya ketentuan KUHAP yang mengatur tentang batas waktu penyelesaian perkara pidana, khususnya bagi tersangka atau terdakwa yang tidak mengalami penahanan, tersangka/terdakwa yang penahanannya dialihkan dari tahanan pada rumah tahanan negara (rutan) menjadi tahanan rumah atau tahanan kota, atau tersangka/terdakwa yang dikeluarkan dari tahanan demi hukum, karena masa penahanan sebagaimana diatur di dalam KUHAP telah habis.

Ketiadaan pengaturan tentang batas waktu penyelesaian perkara pidana bagi tersangka/terdakwa dengan keadaan tersebut di atas, dapat menyebabkan penanganan perkara berjalan demikian lama dan berlarut-larut. Tanpa batas waktu yang jelas, maka penegak hukum pada masing-masing tingkatan tidak memiliki target penyelesaian perkara bersangkutan, sedemikian sehingga penanganan perkara menjadi tidak efektif dan efisien.

Dapat dibayangkan, tanpa ketentuan yang mengatur secara jelas dan tegas tentang batas waktu penyelesaian perkara pidana terhadap tersangka atau terdakwa yang tidak ditahan, pelimpahan perkara dari penyidik ke jaksa penuntut umum, penetapan waktu persidangan dan majelis hakim yang menyidangkan, proses pemeriksaan di sidang Pengadilan tingkat pertama, pengiriman berkas ke tingkat banding, pemeriksaan di tingkat banding, pengiriman berkas ke tingkat kasasi, pemeriksaan oleh hakim kasasi, pengiriman putusan dari Mahkamah Agung ke pengadilan tingkat pertama dan Kejaksaan, dapat dilakukan kapan saja tanpa target yang jelas.

Keadaan yang demikian, di samping tidak akan mampu memenuhi asas peradilan yang dilakukan dengan cepat, sederhana, dan biaya ringan sebagaimana diamanatkan 
KUHAP sebagai payung hukum acara pidana nasional, melainkan juga dapat dimanfaatkan oleh penegak hukum yang tidak bertanggungjawab dan bermental korup, untuk melakukan pemufakatan jahat (judicial corruption) dengan tersangka/terdakwa.

Penegak hukum yang bermental mafia, akan dengan mudah mengulur-ulur atau memperlambat penanganan perkara pidana terhadap tersangka/terdakwa yang tidak ditahan. Berbagai modus dapat dimainkan oleh oknum penegak hukum tertentu karena kelemahan ketentuan KUHAP tersebut, antara lain dengan memperlambat bahkan menahan pelimpahan perkara dari penyidik dan seterusnya, memperlambat jalannya sidang dan mengulur-ulur kehadiran saksi-saksi. Apabila telah jatuh putusan, dapat dilakukan penundaan pengiriman berkas ke tingkat banding, melambat-lambatkan pemeriksaan di tingkat banding dan seterusnya. Apabila putusan banding telah dijatuhkan, dilakukan modus yang sama yakni memperlambat pengiriman berkas ke tingkat kasasi dan pemeriksaan oleh hakim kasasi. Kemudian, manakala putusan kasasi telah dijatuhkan dan putusan telah memiliki kekuatan hukum tetap, oknum penegak hukum yang bermental mafia itu, akan menunda pengiriman berkas putusan dari Mahkamah Agung ke pengadilan tingkat pertama dan Kejaksaan, sedemikian sehingga putusan tidak dapat dieksekusi.

Dalam keadaan yang lain, sangat mungkin dilakukan oleh oknum penegak hukum untuk mengendapkan putusan tersebut di Mahkamah Agung selama waktu tertentu, sedemikian sehingga terpidana yang tidak ditahan, dialihkan penahanannya atau dikeluarkan demi hukum tersebut, tidak perlu menjalani pidana selama yang diperintahkan oleh putusan majelis hakim.

Lebih jelasnya, mengingat bahwa ketentuan Pasal 22 ayat (5) KUHAP yang menjelaskan bahwa "Untuk penahanan kota pengurangan tersebut seperlima darijumlah lamanya waktu penahanan sedangkan untuk penahanan rumah sepertiga dari jumlah lamanya waktu penahanan", maka apabila seorang tersangka/terdakwa dikenakan tahanan kota dan dijatuhi hukuman selama 2 (dua) tahun, maka sang mafia hukum akibat kelemahan Undang-undang, akan berupaya mengendapkan putusan majelis kasasi di Mahkamah Agung, selama 6 (enam) tahun atau kurang sedikit, sedemikian sehingga si terpidana hanya perlu menjalani pidana selama paling lama 2 (dua) atau 3 (tiga) bulan saja.

Bahkan ekstrimnya, untuk kasus-kasus pidana yang tidak menarik perhatian publik dan/atau putusan pidananya ringan, bukan tidak mungkin oknum mafia hukum akan menghilangkan berkas perkara dimaksud. Hilang selama pengiriman baik pada saat 
permohonan kasasi, maupun ketika pengiriman putusan dari Mahkamah Agung ke pengadilan dan kejaksaan, sedemikian sehingga terpidananya tidak pernah dieksekusi.

Terkait kelemahan pengaturan di dalam KUHAP, sebagaimana terjadi pada pengaturan tentang batas waktu penyelesaian perkara pidana terhadap bagi tersangka atau terdakwa yang tidak mengalami penahanan, tersangka/terdakwa yang penahanannya dialihkan dari tahanan pada rumah tahanan negara (rutan) menjadi tahanan rumah atau tahanan kota, atau tersangka/terdakwa yang dikeluarkan dari tahanan demi hukum, karena masa penahanan sebagaimana diatur di dalam KUHAP telah habis tersebut, Mardjono Reksodiputro, mengemukakan bahwa "setelah berjalan lebih dari dua dekade, banyak kelemahan yang ditemukan dalam perumusan KUHAP, sedemikian sehingga KUHAP sering-kali disalah-gunakan untuk kepentingan kekuasaan (abuse of power), dalam tahap penyidikan dan penuntutan". ${ }^{24}$

Senada dengan itu, KHN RI merilis bahwa meskipun KUHAP memberikan perlindungan pada hak tersangka/ terdakwa/terpidana tetapi terdapat ketentuan pasal KUHAP yang memberikan kewenangan yang besar kepada Kepolisian dam Kejaksaan dalam proses hukum pidana yang berpotensi menimbulkan arogansi kekuasaan (the arrogance of power) yang selalu berbarengan dengan penyalah-gunaan kekuasaan (abuse of power). ${ }^{25}$

Penyalah-gunaan kekuasaan berupa pemufakatan jahat antara oknum penegak hukum yang menginginkan imbalan dengan terdakwa/tersangka yang menghendaki agar perkaranya ditunda, dilambat-lambatkan atau diendapkan, secara nyata akan sangat melemahkan penegakan hukum, menciderai rasa keadilan dan kepastian hukum bagi korban, keluarga korban dari tindak pidana yang dilakukan oleh pelaku, dan masyarakat luas terutama dalam tindak pidana-tindak pidana korupsi, pencucian uang, dan sebagainya.

Berdasarkan uraian di atas, disimpulkan bahwa dalam perspektif hukum acara pidana Indonesia, pengaturan mengenai pemenuhan asas peradilan yang cepat, sederhana dan biaya ringan diatur di dalam asas ke lima KUHAP yang menegaskan bahwa "Peradilan yang harus dilakukan dengan cepat, sederhana dan biaya ringan serta bebas, jujur dan tidak memihak harus diterapkan secara konsekuen dalam seluruh tingkat peradilan”. Ketentuan mengenai asas peradilan cepat, sederhana, dan biaya ringan tersebut, kemudian ditegaskan kembali dalam ketentuan yang mengatur tentang hak-hak tersangka/terdakwa,

\footnotetext{
${ }^{24}$ Ibid.

${ }^{25}$ Komisi Hukum Nasional Republik Indonesia, Loc. Cit.
} 
sebagaimana termaktub di dalam Pasal 50 KUHAP, yang menggariskan bahwa "Tersangka berhak segera mendapat pemeriksaan oleh penyidik dan selanjutnya segera diajukan kepada Penuntut Umum, dimajukan ke pengadilan, dan segera diadili oleh pengadilan". Selanjutnya, asas peradilan yang dilakukan dengan sederhana, cepat dan berbiaya ringan, juga diatur di dalam Pasal 2 ayat (4) Undang-Undang Nomor 48 Tahun 2009 tentang Kekuasaan Kehakiman, yang menyatakan bawa "ditegaskan bahwa "Peradilan dilakukan dengan sederhana, cepat, dan biaya ringan”. Kemudian, untuk menjamin terselenggaranya proses peradilan yang cepat, dan menjauhkan kemungkinan terkatung-katungnya nasib seorang yang disangka melakukan tindak pidana terutama mereka yang dikenakan penahanan, jangan sampai lama tidak mendapat pemeriksaan sehingga dirasakan tidak adanya kepastian hukum, adanya perlakuan sewenang-wenang dan tidak wajar, KUHAP mengatur sejumlah ketentuan, antara lain mengenai batas waktu penahanan, sebagaimana termaktub di dalam Pasal 20 sampai dengan Pasal 31 KUHAP. Dengan adanya batas waktu maksimum seseorang boleh dikenakan penahanan, maka penegak hukum pada masingmasing tingkatan akan dipacu untuk bekerja secara efektif menyelesaikan perkara pidana yang menjadi kewajibannya. Resiko yang harus dihadapi oleh penegak hukum dimaksud, manakala penanganan perkara tidak dapat diselesaikan sebelum batas waktu penahanan adalah dikeluarkannya tersangka/terdakwa dari tahanan demi hukum. Jaminan terselenggaranya peradilan yang cepat, sederhana dan berbiaya ringan akibat adanya ketentuan KUHAP yang mengatur tentang penetapan batas penahanan tersebut, tidak terjadi manakala sejak penyidikan tersangka/terdakwa tidak pernah dikenakan penahanan, dialihkan jenis penahanannya, atau dikeluarkan dari tahanan demi hukum karena penanganan perkara pidana telah melewati batas waktu penahanan yang dimungkinkan oleh KUHAP. Persoalan tersebut timbul karena tidak adanya ketentuan KUHAP yang mengatur tentang batas waktu penyelesaian perkara pidana, khususnya bagi tersangka atau terdakwa yang tidak mengalami penahanan, tersangka/terdakwa yang penahanannya dialihkan dari tahanan pada rumah tahanan negara (rutan) menjadi tahanan rumah atau tahanan kota, atau tersangka/terdakwa yang dikeluarkan dari tahanan demi hukum, karena masa penahanan sebagaimana diatur di dalam KUHAP telah habis. Dengan demikian, dalam persepektif perundang-undangan dalam kaitan dengan pemenuhan asas peradilan yang cepat, sederhana dan biaya ringan, terdapat norma yang kosong (vacuum of norm) di dalam KUHAP yang mengatur tentang batas waktu penyelesaian perkara pidana terhadap tersangka atau terdakwa yang tidak dikenakan penahanan. Kekosongan norma hukum 
tersebut sangat berpotensi melemahkan penegakan hukum karena menimbulkan ketidakpastian hukum, ketidak-adilan hukum, dan ketidak-manfaatan hukum di tengah masyarakat.

3. Konsepsi Mengenai Penyelesaian Perkara Pidana yang Sebaiknya Diterapkan di Dalam KUHAP yang Akan Datang

Berangkat dari kesimpulan pada bagian sebelumnya, maka konsepsi pembaharuan hukum acara pidana yang hendak diajukan adalah penyusunan norma baru yang mengatur mengenai batas waktu penyelesaian perkara pidana khususnya bagi tersangka/terdakwa yang tidak mengalami penahanan, tersangka/terdakwa yang penahanannya dialihkan dari tahanan pada rumah tahanan negara (rutan) menjadi tahanan rumah atau tahanan kota, atau tersangka/terdakwa yang dikeluarkan dari tahanan demi hukum, sedemikian sehingga KUHAP yang baru, memuat ketentuan yang jelas dan tegas tentang batas waktu paling lambat sebuah perkara pidana harus diselesaikan.

Ketentuan yang jelas dan tegas tersebut, akan menutup celah bagi tersangka atau terdakwa untuk melakukan pemufakatan jahat dengan oknum penegak hukum untuk mengulur-ulur penyelesaian perkara. Di samping itu, kejelasan dan ketegasan norma tentang batas waktu penyelesaian perkara pidana, akan mampu memenuhi salah satu hakikat hukum acara, yakni peradilan yang dilakukan dengan cepat, sederhana dan biaya ringan. Pencapaian hakikat atau asas hukum acara pidana dimaksud, pada gilirannya akan melahirkan kepastian hukum, keadilan dan kemanfaatan hukum di tengah masyarakat.

Berangkat dari pemikiran bahwa instrumen yang paling efektif untuk mencapai asas peradilan yang dilakukan dengan cepat, sederhana, dan biaya ringan adalah batas waktu penahanan, sebagaimana diatur di dalam Pasal 20 sampai dengan Pasal 31 KUHAP, maka norma yang diajukan terkait pelaksanaan peradilan yang cepat, sederhana, dan biaya ringan demi tercapainya kepastian hukum dan keadilan, baik bagi tersangka/terdakwa, korban tindak pidana yang dilakukan oleh tersangka/terdakwa, dan masyarakat pada umumnya, adalah memberikan perlakuan yang sama terhadap semua tersangka, yakni dengan mengenakan penahanan.

Sudah lama menjadi perdebatan bahwa wewenang diskresi atau wewenang untuk bertindak atas pertimbangan sendiri yang dimiliki oleh penegak hukum, untuk menahan atau tidak menahan seorang tersangka, sebagaimana diatur di dalam Pasal 21 KUHAP, mengandung banyak kelemahan. 
Disamping, dinilai bersifat subyektif dan multi tafsir sehingga sangat berpotensi menciderai asas KUHAP yakni persamaan di depan hukum (equality before the law), ketentuan pasal tersebut di atas juga dapat dimanfaatkan oleh penegak hukum yang tidak bertanggung jawab, sebagai senjata ampuh berupa kewenangan yang luas dan otonom tersebut digunakan sebagai alat "pemerasan" kepada tersangka untuk membayar dengan jumlah tertentu agar ianya tidak ditahan.

Bila demikian halnya, tentu tidak mungkin mengharapkan akan terjadi upaya penegakan hukum yang optimal. Upaya memberantas tindak pidana bukannya mampu menghapus kejahatan sampai ke akar-akarnya, melainkan justeru menyuburkan perbuatan pidana baru yang dilakukan oleh penegak hukum yang bermental korup, akibat kelemahan perumusan perundang-undangan. Situasi yang demikian, membuat kita seakan berada dalam keadaan dimana harus menyapu rumah yang kotor dengan sapu yang kotor.

Berdasarkan paparan di atas, kiranya jelas bahwa kelemahan perumusan ketentuan KUHAP yang mengatur mengenai penetapan penahanan, baik langsung maupun tidak langsung dapat melemahkan penegakan hukum yang efektif, yang salah satunya ditandai dengan pelaksanaan asas KUHAP, berupa peradilan yang dilakukan dengan cepat, sederhana dan biaya ringan.

Oleh karena itu, penelitian ini merekomendasikan bahwa demi pencapaian asas peradilan yang dilakukan dengan cepat, sederhana, dan biaya ringan, maka instrumen yang paling efektif dipergunakan adalah ketentuan yang mengatur tentang batas waktu penahanan, sebagaimana diatur di dalam Pasal 20 sampai dengan pasal 31 KUHAP. Agar ketentuan pasal-pasal dimaksud dapat diberlakukan secara efektif, maka harus dimuat satu ketentuan pokok di dalam KUHAP yang akan datang, yang pada prinsipnya mengatur bahwa setiap kali penetapan seseorang menjadi tersangka, maka kepadanya otomatis dilakukan penahanan.

Pandangan tersebut berangkat dari pemikiran bahwa manakala penetapan tersangka telah dilakukan dengan mengedepankan prinsip-prinsip kecermatan dan kehati-hatian, penghormatan terhadap hak-hak tersangka dan harus bebas dari kepentingan apapun selain untu mencapai tujuan penegakan hukum serta memenuhi prinsip-prinsip "due process of law", maka tersangka tersebut adalah benar-benar merupakan pelaku dari tindak pidana yang disangkakan.

Dengan demikian, manakala telah benar-benar terdapat bukti hukum yang kuat bahwa sebuah tindak pidana telah benar-benar telah terjadi dan tersangka tersebut adalah 
benar-benar merupakan pelaku dari tindak pidana tersebut, maka hal itu telah menjadi alasan yang kuat untuik melakukan penahanan terhadap seorang tersangka pelaku tindak pidana.

Dengan kata lain dapat dikatakan bahwa prosedur penetapan tersangka yang telah memenuhi prinsip-prinsip "due process of law", merupakan parameter yang sahih dan kriteria yang jelas dan tegas untuk melakukan penahanan terhadap seorang tersangka perkara. Artinya, manakala seseorang telah ditetapkan sebagai tersangka, maka otomatis terhadap orang tersebut harus dilakukan penahanan.

Manakala sudah ditetapkan sebagai tersangka, sesungguhnya tidak ada alasan yang dapat diterima akal sehat untuk menunda-nunda penahanan, sebagaimana yang telah menjadi kerancuan hukum selama ini, akibat kelemahan ketentuan perundang-undangan.

Bagi sebagian orang, mungkin pendapat ini terkesan terlalu menyederhanakan persoalan. Banyak hal harus dipertimbangkan manakala harus menetapkan penahanan terhadap seseorang karena menyangkut penahanan tersebut berkaitan erat dengan pengekangan terhadap hak asasi manusia.

Namun pendapat di atas dilandasi pemikiran bahwa pertimbangan ${ }^{1}$ ' $\mathrm{p}$ hak asasi manusia terutama hak-hak tersangka, seyogyanya tidak menjadi pertimbangan pada saat penetapan penahanan, melainkan pada saat seseorang itu ditetapkan menjadi tersangka.

Dengan penetapan penahanan secara serta merta pada saat seseorang dijadikan tersangka suatu tindak pidana, maka diyakini penegak hukum akan bekerj ksimal untuk menyelesaikan perkara pidana bersangkutan secara tepat waktu, sehingga tidak terjadi pengeluaran tersangka/terdakwa dari tahanan demi hukum. Dengan demikian, maka salah satu asas yang menjadi kriteria keberhasilan penegakan hukum yakni peradilan yang dilakukan dengan cepat, sederhana dan berbiaya ringan, sebagaimana menjadi amanat KUHAP, akan dapat dicapai secara efektif.

\section{E. Kesimpulan}

Berdasarkan uraian diatas, maka dapat diambil beberapa kesimpulan sebagai berikut :

1. Pengaturan mengenai penyelesaian perkara piadana yang ditandai dengan pemenuhan asas peradilan yang dilakukan dengan cepat, sederhana dan biaya ringan diatur di dalam asas-asas KUHAP, Pasal 50 KUHAP, dan Pasal 2 ayat (4) Undang- 
Undang Nomor 48 Tahun 2009 tentang Kekuasaan Kehakiman. Hakikat pengaturan tersebut di atas, adalah untuk menjauhkan kemungkinan terkatung-katungnya nasib seorang yang disangka melakukan tindak pidana terutama mereka yang dikenakan penahanan, jangan sampai lama tidak mendapat pemeriksaan sehingga dirasakan tidak adanya kepastian hukum, adanya perlakuan sewenang-wenang dan tidak wajar. Untuk menjamin pelaksanaan asas KUHAP dimaksud, diatur sejumlah ketentuan antara lain mengenai batas waktu penahanan, sebagaimana termaktub di dalam Pasal 20 sampai dengan Pasal 31 KUHAP.

2. Implementasi penyelesaiannya adalah dalam hal batas waktu maksimum seseorang dapat dikenakan penahanan, maka penegak hukum pada masing-masing tingkatan akan dipacu untuk bekerja secara efektif menyelesaikan perkara pidana secara tepat waktu. Namun demikian, jaminan terselenggaranya peradilan yang cepat, sederhana dan berbiaya ringan akibat adanya ketentuan KUHAP yang mengatur tentang penetapan batas penahanan tersebut, tidak tercapai manakala tersangka/terdakwa tidak dikenakan penahanan.Hal itu tidak terjadi karena tidak adanya ketentuan KUHAP yang mengatur tentang batas waktu penyelesaian perkara pidana, khususnya bagi tersangka atau terdakwa yang tidak mengalami penahanan, penahanannya dialihkan, atau tersangka/terdakwa yang dikeluarkan dari tahanan demi hukum. Kekosongan norma hukum tersebut sangat berpotensi melemahkan penegakan hukum karena menimbulkan ketidak-pastian hukum, ketidak-adilan hukum, dan ketidak-manfaatan hukum di tengah masyarakat.

3. Pengaturanpenyelesaian perkara pidana sebaiknya diatur di dalam KUHAP,seperti halnyapenahanan yang berlaku untuk semua tersangka. Penetapan penahanan yang didasarkan pada wewenang diskresi sebagaimana diatur di dalam pasal 21 ayat (1) KUHAP, secara nyata membuka peluang terjadinya tebang pilih dalam penetapan penahanan, yang tidak saja melemahkan upaya pelaksanaan peradilan yang cepat sederhana, dan biaya ringan, juga mengingkari asas kesamaan di depan hukum.

\section{F. Rekomendasi}

1. Agar ketentuan yang mengatur mengenai pemenuhan asas peradilan yang dilakukan dengan cepat, sederhana, dan berbiaya ringan sebagaimana secara tegas dan jelas diamanatkan di dalam KUHAP dapat diterapkan secara efektif, sedemikian sehingga benar-benar mampu menjamin bahwa pada setiap terjadinya tindak pidana, tersangka 
pelaku dikenakan penahanan, maka ketentuan Pasal 21 ayat (1) KUHAP, harus dicabut dan dinyatakan tidak berlaku..

2. Agar konsepsi norma peradilan pidana yang dilakukan dengan cepat, sederhana, dan berbiaya ringan dapat diwujudkan, maka kepada pihak yang berkompeten direkomendasikan untuk segera melakukan perubahan terhadap perumusan KUHAP, sedemikian sehingga memuat ketentuan yang jelas dan tegas, tentang $\mathrm{si} \quad$ ssuatu yang menyangkut penahanan terhadap semua orang, yang sudah ditetapkan secara hati-hati sebagai tersangka.

\section{G. Daftar Pustaka}

Bernard Arief Sidharta, Refleksi Tentang Struktur Ilmu Hukum, Mandar Maju, Bandung, 2008..

Franz Magnis Suseno, Etika Politik: Prinsip Moral Dasar Kenegaraan Modern, Gramedia, Jakarta, 1993..

L.J. Van Apeldoorn, Pengantar Ilmu Hukum, Jakarta: PT. Pradnya Paramita, Cetakan Kedupuluhenam, Terjemahan: Mr. Oetarid Sadino, 1996.

M. Yahya Harahap, Pembahasan Permasalahan dan Penerapan KUHAP, Penyidikan dan Penuntutan, Sinar Grafika, Jakarta, 2007..

Mardjono ReksodiputroHak Asasi Manusia Dalam Sistem Peradilan Pidana, Kumpulan Karangan Buku Ketiga, Pusat Pelayanan Keadilan dan Pengabdian Hukum (d/h Lembaga Kriminologi Universitas Indonesia, Jakarta, 2007.

Mochtar Kusumaatmadja dan B. Arief Sidharta, Pengantar Ilmu Hukum, Suatu Pengenalan Pertama Ruang Lingkup Berlakunya Ilmu Hukum, Alumni, Bandung, 2000.

Padmo Wahjono, Indonesia Negara Berdasarkan Atas Hukum, Ghalia Indonesia, Jakarta, 1982.

Siswantoro Sunarso. Penegakan Hukum Psikotropika Dalam Kajian Sosiologi Hukum, Rajawali Pers, Jakarta, 2004..

Soerjono Soekanto, Faktor-faktor yang Mempengaruhi Penegakan Hukum, CV. Rajawali, Jakarta, 1983..

Sudarto. Kapita Selekta Hukum Pidana, Alumni Bandung, 1981.

Sudikno Mertokusumo,.Mengenal Hukum Suatu Pengantar, Liberty Yogyakarta, Yogyakarta, 2007.

Soerjono Soekanto, Pengantar Penelitian Hukum, Universitas Indonesia (UI-Press), Jakarta, 1984.

Padmo Wahjono, Indonesia Negara Berdasarkan Atas Hukum, Ghalia Indonesia, Jakarta, 1982.

Utrecht, Pengantar Hukum Administrasi NegaraIndonesia, Ichtiar, Jakarta, 1962

Bernard Arief Sidharta, Refleksi Tentang Struktur Ilmu Hukum, Mandar Maju, Bandung, 2000. 